\title{
PRORAČUN KONSTRUKCIJE ČELIČNE HALE SA KRANSKOM STAZOM PREMA EVROKODU
}

\section{STRUCTURAL DESIGN OF STEEL HALL WITH RUNWAY BEAM ACCORDING TO EUROCODE}

Miloš Ivković, Fakultet tehničkih nauka, Novi Sad

\begin{abstract}
Oblast - GRAĐEVINARSTVO
Kratak sadržaj - U radu je dat proračun čelične skladišne hale sa kranskom stazom prema SRPS EN standardima. Prikazan je statički proračun svih konstruktivnih elemenata $i$ njihovo dimenzionisanje. Pored priložene grafičke dokumentacije (dispozicioni crteži, detalji veza), $u$ radu je dat $i$ detaljan proračun karakterističnih montažnih nastavaka. Teorijsko-istraživački deo rada se odnosi na metode proračuna usled zamora materijala.
\end{abstract}

Ključne reči: Evrokod, čelična hala, kranska staza, zamor.

\begin{abstract}
This master thesis desribes calculation of steel hall with a crane supporting beam according to Eurocode standard. The complete static calculation of all structural elements as well as their design were performed and presented. Aside from presented graphic documentation (steel details, details of connections), paper describes detaild calculation of characteristic splice joints. Theoretical and explorative part of the paper deals with fatique of the materials.
\end{abstract}

Keywords: Eurocode, steel hall, runway beam, fatique

\section{UVOD}

Zadatkom je predviđena izrada projektnog rešenja industrijske skladišne hale sa unutrašnjim transportom pomoću mostnog krana nosivosti 5 t. Hala je jednobrodna sa rasponom od $20,5 \mathrm{~m}$. Objekat je u osnovi dimenzija $20,5 \times 42,0 \mathrm{~m}$.

\section{ANALIZA OPTEREĆENJA KRANSKE STAZE}

\subsection{Osnovni podaci o kranskoj stazi}

Statički sistem kranske staze na koju je oslonjen mostni kran je kontinualni nosač na 7 polja raspona $6,0 \mathrm{~m}$. Usvojen je poprečni presek kranskog nosača HEA260. Evrokod razlikuje vertikalna i horizontalna opterećenja koja je neophodno uzeti u obzir pri proračunu i dimenzionisanju kranske staze.

U slučaju vertikalnih opterećenja neophodno je razmatrati dva slučaja opterećenja i odrediti minimalnu odnosno maksimalnu vertikalnu silu $Q_{r, \max } i Q_{r, \min }$, slika 1 . i 2 .

\section{NAPOMENA:}

Ovaj rad proistekao je iz master rada čiji mentor je bila v. prof dr Jelena Dobrić, dig.
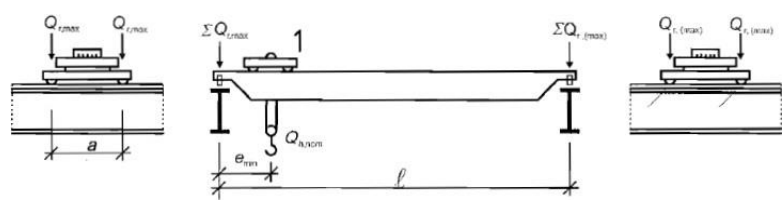

Slika 1. Raspored opterećenja za dobijanje maksimalnog pritiska točka dizalice (mačka opterećena) [1]

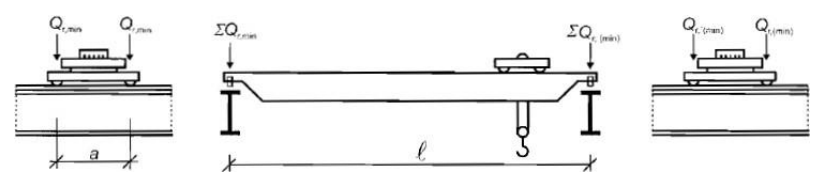

Slika 2. Raspored opterećenja za dobijanje minimalnog pritiska točka dizalice (mačka neopterećena) [1]

Horizontalna opterećenja razlikujemo kao opterećenja nastala ubrzanjem ili kočenjem krana (sl. 3) i horizontalna opterećenja nastala zakošenjem krana (sl. 4). Intenzitet ovih opterećenja se određuje na osnovu izraza koje propisuje Evrokod.

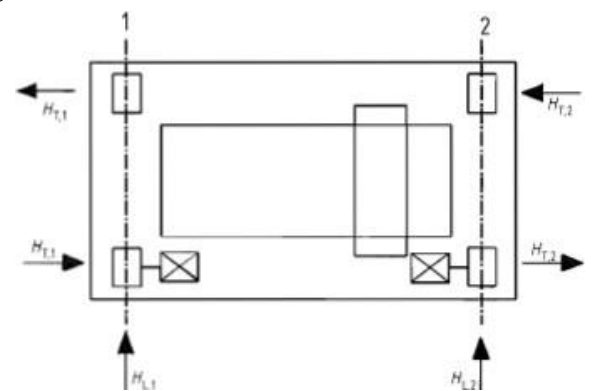

Slika 3. Dejstvo sila izazvanih ubrzanjem ili kočenjem [1]

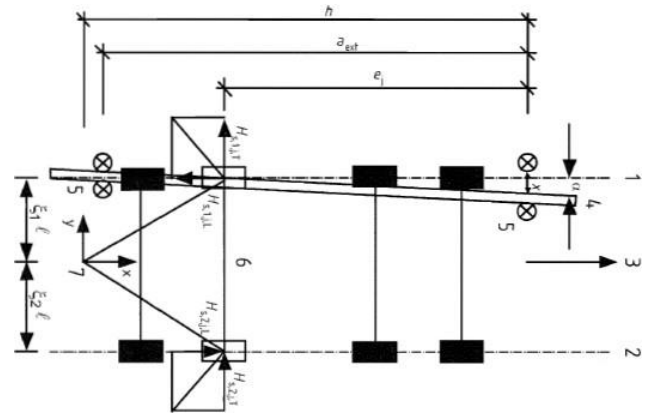

Slika 4. Dejstvo sila izazvanih zakošenjem krana [1]

Sva opterećenja je neophodno uvećati dinamičkim faktorom opterećenja $\varphi_{i}$ koji zavisi od kombinacije opterećenja pri čemu prema Evrokodu razlikujemo sedam različitih kombinacija opterećenja [1]. 


\section{PRORAČUN KRANSKE STAZE}

\subsection{Otpornost preseka na savijanje}

Proračunska vrednost momenta nosivosti poprečnog preseka $\mathrm{M}_{\mathrm{c}, \mathrm{Rd}}$ zavisi od klase poprečnog preseka [2].

Za preseke klase 1 i 2 koristi se plastičan model ponašanja $\left(\mathrm{M}_{\mathrm{pl}}\right)$.

Za preseke klase 3 primenjuje se elastična lokalna analiza $\left(\mathrm{M}_{\mathrm{el}}\right)$.

Za poprečne preseke klase 4 nosivost se određuje takođe primenom elastične analize, ali sa efektivnim poprečnim presekom usled izbočavanja $\left(\mathrm{M}_{\mathrm{eff}}\right)$.

Uslov koji treba da bude zadovoljen je dat izrazom (1):

$$
\frac{M_{e d}}{M_{p l, y, R d}}<1.0
$$

$\mathrm{M}_{\mathrm{ed}}$ - proračunska vrednost momenta savijanja

$\mathrm{M}_{\mathrm{pl}, \mathrm{y}, \mathrm{Rd}}$ - proračunska nosivost poprečnog preseka na savijanje.

\subsection{Otpornost preseka na smicanje}

Uslov koji treba da bude zadovoljen je dat izrazom (2):

$$
\frac{V_{e d}}{V_{c, R d}}<1.0
$$

$\mathrm{V}_{\text {ed }}$ - proračunska vrednost sile smicanja $\mathrm{u}$ razmatranom pravcu

$\mathrm{V}_{\mathrm{c}, \mathrm{Rd}}$ - odgovarajuća proračunska nosivost poprečnog preseka na smicanje.

\subsection{Izbočavanje usled lokalnog pritiska točka}

Poprečne sile koje deluju u ravni rebra punih nosača mogu da prouzrokuju lokalni gubitak stabilnosti rebra. Ukoliko je opterećenje na nosaču fiksno ovaj problem se lako rešava formiranjem ukrućenja na mestu delovanja opterećenja. Ukoliko se radi o pokretnom opterećenju kao što je slučaj sa opterećenjem kranskog nosača mora biti obezbeđena nosivost rebra na izbočavanje usled dejstva lokalnih sila.

Do iscrpljenja nosivosti rebra nosača usled delovanja lokalne koncentrisane sile može doći ulubljenjem rebra u obliku lokalizovanog izbočavanja [3] i plastifikacije neposredno ispod nožica praćenog plastifikacijom (sl. 5.).

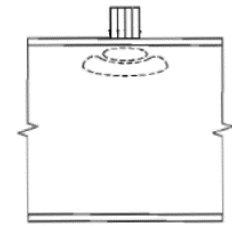

Slika 5. Lokalizovano izbočavanje rebra [3]

Uslov nosivosti koji treba da bude zadovoljen je dat izrazom (3):

$$
\frac{F_{\mathrm{E} d}}{F_{R d}}<1.0
$$

Sila otpora na koncentrisane sile je prikazana izrazom (4):

$$
F_{R d}=\frac{f_{y w} * L_{e f f} * t_{w}}{\gamma_{M 1}}
$$

$\mathrm{L}_{\text {eff }}$ - efektivna širina

$\mathrm{f}_{\mathrm{yw}}-$ granica razvlačenja rebra

\subsection{Bočno torziono izvijanje}

Bočno torziono izvijanje je posledica dostizanja kritične vrednosti opterećenja te deformacije nosača izvan ravni delovanja opterećenja praćene torziom.

Kao osnov za proračun nosivosti elementa na bočnotorziono izvijanje u Evrokodu 3 koristi se kritični moment tj. minimalna teorijska vrednost momenta savijanja $u$ kritičnom preseku pri kojoj dolazi do gubitka stabilnosti elementa usled bočno-torzionog izvijanja [2].

Ukoliko se radi o elementima koji nisu bočno pridržani da bi se zadovoljila nosivost na bočno-torziono izvijanje neophodno je da se zadovolji sledeći izraz (5):

$$
\frac{M_{e d}}{M_{b, R d}}<1.0
$$

$\mathrm{M}_{\mathrm{Ed}}$ - proračunska vrednost momenta savijanja $\mathrm{M}_{\mathrm{b}, \mathrm{Rd}}$ - proračunski moment nosivosti na bočno-torziono izvijanje.

\section{MODELIRANJE KONSTRUKCIJE}

\subsection{Elementi i geometrija}

Proračun statičkih uticaja u elementima $\mathrm{AB}$ konstrukcije je sproveden pomoću specijalizovanog softvera za strukturalnu analizu - Radimpex Tower 8.0.

Formiran je detaljan prostorni model, koji u potpunosti prati geometriju konstrukcije i kojim su predstavljeni svi njeni elementi, kao i odgovarajuća dejstva.

Elementi su modelirani kao linijski (stubovi, grede) ili površinski (temeljna stopa) sa odgovarajućim geometrijskim karakteristikama poprečnih preseka i mehaničkim karakteristikama materijala - čelik S275, armirani beton $\mathrm{C}$ 25/30.

Veze između elemenata su modelirane kao krute ili zglobne.

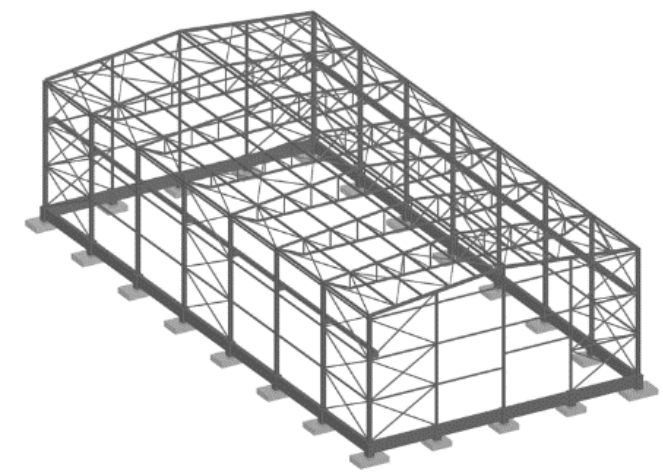

Slika 6. 3D model konstrukcije

\subsection{Konstruktivni sistem}

$\mathrm{Na}$ predmetnoj čeličnoj hali razlikujemo površinske i linijeske elemente. Celokupna konstrukcija je temeljena na temeljima samcima čija je stopa modelirana kao površinski element dok su svi ostali elementi modelirani kao linijski. U temelje samce su uklješteni čelični stubovi, na koje su na gornjem nivou zglobno oslonjeni rešetkasti nosači. Ostali konstruktivni elementi služe za oslanjanje krovnih i zidnih panela, za prostornu stabilizaciju konstrukcije te kao nosači mostnog krana. 


\section{ANALIZA OPTEREĆENJA ČELIČNE HALE}

Proračun opterećenja izvršen je u saglasnosti sa Evrokodom EN 1991. Analizirana su sva opterećenja koja će se javiti na konstrukciji za vreme eksploatacionog veka.

\subsection{Stalno opterećenje}

Kao stalno opterećenje razlikujemo opterećenje konstruktivnih odnosno nekonstruktivnih elemenata [4]. Opterećenje konstruktivnih elemenata aplicirano je u samom programskom paketu Tower 8.0. U nekonstruktivne elemente uvrštavaju se krovne i zidne obloge i sve vrste instalacija (elektro, mašinske i sl.).

\subsection{Promenljivo opterećene}

Kao promenljivo opterećenje na predmetnom modelu analizirano je opterećenje vetrom i opterećenje snegom [5,6]. Opterećenje snegom dato je Evrokodom EN 19911-3. Dobija se na osnovu obrazca $s=\mu_{i} * C_{e} * C_{t} * s_{k}$, gde je:

$s_{k}$ karakteristična vrednost opterećenja od snega na tlo na relevantnoj lokaciji.

Opterećenje vetrom je predmet razmatranja Evrokoda EN 1991-1-4. Osnovni parameter pri određivanju ovog opterećenja jeste fundamentalna osnovna brzina vetra

$V_{b, o}$ koja se očitava sa mapa definisanih od strane RHMZ Srbije a zavisno od lokacije objekta. Za lokaciju Novi Sad $V_{b, o}=21,0 \mathrm{~m} / \mathrm{s}$.

\subsection{Seizmičko opterećenje}

Seizmičko opterećenje je funkcija seizmičke lokacije objekta te od dinamičkih karakteristika sistema objekattlo. Stoga je proračun baziran na proračunu modalne analize na osnovu koje se dobijaju dinamičke karakteristike same konstrukcije odnosno periodi oscilovanja na osnovu kojih se vrši dalji proračun samog opterećenja. Seizmičko opterećenje je detaljno opisano Evrokodom EN 1998.

Kao parametar lokacije daje se referentno ubrzanja tla $\mathrm{a}_{\mathrm{gR}}$. Za lokaciju Novi Sad $a_{g R}=0,10 g$. Kako bi se odredilo seizmičko opterećenje neophodno je poznavanje karakteristika tla, klase duktilnosti i klase značaja objekta.

Evrokod propisuje dve metode proračuna seizmičkog opterećenja: metoda ekvivalentnih bočnih sila i multimodalna spektralna analiza, pri čemu je za proračun seizmičkih sila predmetnog objekta izabrana multimodalna spektralna analiza [7].

\section{STATIČKI PRORAČUN I DIMENZIONISANJE ELEMENATA KONSTRUKCIJE}

\subsection{Kombinacije opterećenja}

Prilikom projektovanja kostrukcija prema Evrokodu razmatraju se najnepovoljnije kombinacije opterećenja koje mogu istovremeno da deluju na konstrukciju. Razlikujemo kombinacije za stalne i prolazne situacije, incidentne situacije i seizmičke proračunske situacije.

Ove kombinacije formirane su za proveru graničnih stanja nosivosti, dok su za proveru graničnih stanja upotrebljivosti korišćene karakteristične kombinacije opterećenja [8].

\subsection{Statički proračun i dimenzionisanje elemenata}

U sklopu ovog poglavlja izvršen je proračun elemenata pri čemu je izvršena: kontrola napona, otpornost na pritisak, otpornost na savijanje, otpornost na smicanje, nosivost na kombinaciju savijanja i aksijalne sile, nosivost na kombinaciju smicanja i savijanja, nosivost na kombinaciju savijanja, smicanja i aksijalne sile, nosivost na fleksiono izvijanje i dokaz bočno-torzionog izvijanja. Izvršena je i provera vertikalnih odnosno horizontalnih ugiba u zavisnosti od položaja elementa u konstrukciji $[2,9]$.

\section{ZAKLJUČAK}

Do loma konstrukcije može doći i pri naponima koji ne dostižu granične vrednosti. Zamor materijala je proces postepene propagacije prsline izazvane promenama naprezanja koje se ponavnjaju. Opterećenja koje mogu da dovedu do loma konstrukcije usled zamora su promenljiva opterećenja koja se višestruko ciklično menjaju, osciluju između gornje i donje granice napona. $\mathrm{Na}$ lom direktno utiče naponska razlika.

Lom izazvan zamorom materijala karakteriše odsustvo plastične deformacije koja nastaje na mestima malih defekata, oštećenja ili nesavršenosti osnovnog materijala ili na mestima šavova. Na takvim mestima u konstrukciji pri naizmeničnom naprezanju promenljivim opterećenjem dolazi do neravnomerne preraspodele napona koja se ogleda u stvaranju lokalnih koncentracija napona Mehanizam zamora se može okarakterisati kao progresivno povećanje $\mathrm{i}$ širenje pukotine na mestu diskontinuiteta $u$ kritičnom preseku dinamički opterećenog elementa, kojim se smanjuju je nosivost kritičnog preseka [10,11].

\section{LITERATURA}

[1] EN 1991-3 Actions on structures - Part 3: Actions induced by cranes and machinery

[2] EN 1993-1-1 Proračun čeličnih konstrukcija (Opšta pravila i pravila za zgrade)

[3] EN 1993-1-5 Design of steel structures - Part 1-5: General rules - Plated structural elements

[4] EN 1991-1-1 Dejstva na konstrukcije (Zapreminske težine, sopstvene težine, korisna opterećenja za zgrade)

[5] EN 1991-1-4 Dejstva na konstrukcije (Dejstva vetra)

[6] EN 1991-1-3 Dejstva na konstrukcije (Dejstva snega)

[7] EN 1998-1 Proračun seizmički otpornih konstrukcija (Opšta pravila, seizmička dejstva i pravila za zgrade)

[8] EN 1990 Eurocode - Basis of structural design

[9] EN 1993-6 Design of steel structures - Part 6: Crane supporting structures

[10] EN 1993-1-9 Design of steel structures - Part 9: Fatique

[11] Z. Marković „Granična stanja čelilnih konstrukcija prema Evrokodu“, Akademska misao, Beograd, 2019.

\section{Kratka biografija:}

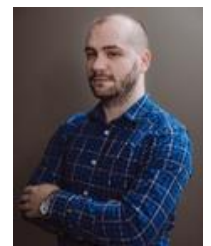

Miloš Ivković rođen je u Sremskoj Mitrovici 1990. god. Master rad na Fakultetu tehničkih nauka odbranio je 2021.god.

kontakt: milosivkovic@ymail.com 